\title{
DISCUSSION OF CAUSALITY BASED ON THE CONCEPTIONS OF NATURE OF IBN RUSHD AND AL-GHAZĀLi
}

\author{
Mehmet Fatih Birgül \\ Muş Alparslan University, Muş-Turkey
}

\begin{abstract}
In this short analysis, we will compare Ibn Rushd's justification of the causality principle to the suspicions and objections of al-Ghazālī. Nevertheless, our analysis of the issue will center on al-Ghazālī's and Ibn Rushd's conceptions of nature. Therefore, our article aims at illuminating two points: first, there is a fundamental difference between the conceptions of nature and generation of the two philosophers; second, this structural difference constitutes the real cause of disagreement over the causality principle.
\end{abstract}

Keywords: Ibn Rushd, al-Ghazālī, causality, nature, determinism, generation.

When studying the history of philosophy, one will find serious objections to causality even as early as antiquity. Aristotle's conflict with the Sophists, who ignore absolute knowledge and even being itself, is one example. In the Islamic world as well, certain Muslim theologians, especially Ash'arīs, were inclined towards the refusal of causality in nature, as evident in their genuine style. This is why we see that Ibn Rushd, as he identifies his position with Aristotle's, tends to place kalām scholars in the same position as the Sophists.

As a strict follower of Aristotle, Ibn Rushd is actually uncomfortable with Ash'arī kalām to a large extent and is prone to include Ash'arīs in the same category as the Sophists due to certain similarities. It is not an exaggeration to say that one of the major reasons for 
this discomfort arises from their denial of causality. In order to better understand the situation, however, and as an appropriate introduction to the issue, we should revisit the basics to begin our essay with an elaboration of Ibn Rushd's classification of fundamental types of knowledge. Ibn Rushd follows Aristotle exactly and identifies three categories of methodical knowledge in virtue of their approach to being, i.e. philosophy/wisdom (bikma) based on demonstrative proof (burhān); dialectic, and sophistry:

The true philosophy distinguishes from dialectic philosophy in terms of type of knowledge, since true philosophy approaches the being through demonstrational thought, whereas the dialectic deals with it through widely accepted (mashhür) view. As for Sophism, it differentiates with respect to objective in life; as the objective of Sophist is to be deemed as a philosopher even though he is not, just to attain a prestigious status or other worldly benefits. On the other hand, the aim of philosopher is just to know the truth. ${ }^{1}$

Sophistry evidently manifests the ambition to acquire pecuniary advantages or to satisfy individual lust because the sophist does not aim to reach the truth. The dialectic is merely a phase that should be surpassed in the later process of learning, because the real objective is, no doubt, to acquire burhāni knowledge. However, not many achieve this goal because many seekers of knowledge can not go beyond the dialectical phase as a consequence of using the wrong methodology:

This [situation] occurs with many of the young people who learn the science called kalām at the beginning of their education. Because this science aims at making certain views believed to be true superior, these young people are obsessed by the desire to support those [kalamic] arguments through a sophistic approach, which might include ignoring first principles, or even by means of dialectic, rhetoric, or poetic thought. As a result, such views become spontaneously known for persons who grow up listening to them, including the denial of natures and forces, the abolition of obligations in human nature, and making all of them possible (mumkin), the ignorance of

Abū l-Walīd Ibn Rushd al-Hafīè Muḥammad ibn Aḥmad al-Qurțubī, Tafsīr Mā ba`d al-tabī'a (henceforth Tafsìr) (ed. Maurice Bouyges; Beirut: Dār al-Mashriq, 1991), I, 329. 
sensible efficient causes, and the denial of the reasonable necessity between cause and effect. ${ }^{2}$

Therefore, Ibn Rushd establishes a fundamental analogy between kalām scholars, who do not refrain from using dialectical, rhetorical, or even sophistical inferences that are not based on exact knowledge in order to support their own theological views and the Sophists. Moreover, according to Ibn Rushd, most kaläm scholars are unable to overcome views, such as the denial of causality even at the end of their learning process. The reason for this failure is that their mental ability is insufficient or, in other words, their nature is not predisposed:

Most people, due to their nature, are not capable of overcoming dialectical views in order to reach demonstrative thought. When they accept the reasonable ( $\left.m a^{\prime} q \bar{u} l \bar{a} t\right)$, they admit it only on the condition of being widely accepted. Later on, when the opposite of the reasonable is widely accepted, they deny much of the reasonable. This is very similar to the situation of persons who have been associated with a kind of kalām called 'ilm al-Ash'ariyya in our present time, as they have denied the impossibility of a being's coming into existence from nothing ( $\left.\min l \bar{a}-s h a y^{\prime}\right)$, i.e. from non-existence ( $a l^{-}(a d a m)$, even though it is a judgment (qadiyya) commonly agreed by the Ancients, I mean including especially the impossibility of magnitude ( $i z a m$ ) emerging from non-magnitude ( $\min l \bar{a}_{-}{ }^{i} i z a m$ ). Even more, you see that many people dealing with philosophy deny its primariness and that they refute the propriety of forms of species to their substances (ikhtișāṣ al-șuwar al-naw'iyya bi-mawāddihāa). Moreover, we see that Ibn Sinā, despite his renowned status in philosophy, says "it is possible that man can come into existence from clay just like mice"! If he actually believes this and does not affirm such an argument in order to agree with his contemporaries, he should be influenced by his concern with 'ilm al-Ash'ariyya. ${ }^{3}$

This long quotation of the remarks of Ibn Rushd on this issue is due to understand more clearly his evaluation of the denial of causality. As a matter of fact, because of Ash'arīs' manner of approach, the problem of causality in the eyes of Ibn Rushd extends beyond a mere

2 Ibn Rushd, Tafsīr, I, 44.

3 Ibn Rushd, Tafsi $r$, I, 46-47. 
ontological and epistemological subject and becomes an important theme in the field of philosophy of religion.

We can now address the problem of the denial of causality in nature that is considered to be dialectic or even sophistry by Ibn Rushd; of course in the context of conceptions of nature, as our title suggests. The most clear and systematic text for this purpose can be found in Tahäfut al-Tahäfut (The Incoherence of the Incoherence). Therefore we will largely follow this text, and we will try to address the question at a different level by analyzing other works by Ibn Rushd as the need arises.

First, we would like to put two essential findings about the discussion on causality in al-Ghazālì's Tahāfut al-falāsifa:

1. Al-Ghazālī put his objections to causality at the first rank of physics. The order of the book shows us that causality is the most important theme in physics.

2. Information provided by al-Ghazālī regarding physics and objections by Ibn Rushd against it are important data that reveal the difference between the conceptions of nature of the two philosophers. For this reason, the discussion of causality by these great thinkers should be read in a way that enables us to determine the conception of nature of each.

According to al-Ghazālī, the physical sciences are classified into eight fundamental sciences and seven branches $($ far $)$. There is no problem with the fundamental sciences; however, the sciences designated as branches by al-Ghazālī actually do not arise from Aristotle's philosophy. Nevertheless, we should say that al-Ghazālī is not the first to put this classification, and thus he bears no responsibility, because he directly borrowed it from Ibn Sinnā as it was. ${ }^{4}$ Nonetheless, there is no doubt that the silence of al-Ghazāli with respect to Avicennian classification, as is also seen from his words in the discussion, implies his agreement. Importantly, he clearly expresses that

Abū 'Alī Ḥusayn ibn 'Abd Allāh ibn 'Alī Ibn Sīnā, Risāla fì aqsām al-culūm alaqliyya, in Rasā'il fì l-ḥikma wa-l-țabī'iyyāt (Istanbul: Mațba'at al-Jawā'ib, 1298 H.), 75. 
there is no religious need for opposition to these sciences, except in four instances. ${ }^{5}$

Ibn Rushd proposes remarkable criticisms of the classification of "natural sciences", a classification that is directly adopted and related by al-Ghazālī. Al-Ghazālī includes medicine among the natural sciences, whereas according to Ibn Rushd medicine is not one of the natural sciences; it is a practical art taking its principles from the natural sciences. ${ }^{6}$ The disagreement between Ibn Rushd and al-Ghazāli is quite clear, too, with respect to all other sciences which the latter considers among the natural ones. According to Ibn Rushd, astrology ( ${ }^{\mathrm{ilm}}$ aḅkām al-nujūm) and knowledge of discernment ('ilm alfirāsa) are not natural sciences but are kinds of fortune-telling and soothsaying. The interpretation of dreams is not a science at all. Talismanic arts are superstitious, and sorcery has nothing to do with science; chemistry (alchemy) is probably not a science, let alone a natural one. ${ }^{7}$

This classification of science clearly exposes the difference between the conceptions of nature of al-Ghazālī and Ibn Rushd. The nature, according to al-Ghazālī, is not only the subject of medicine and astronomy, but also of astrology, knowledge of discernment, the interpretation of dreams, talismanic art, magic and alchemy; whereas, aside from considering these as tools to examine the nature, Ibn Rushd does not even accept them as sciences.

We should add that, objections by al-Ghazālī against causality are not an investigation of truth or an epistemic problem, but only a defense of faith. Al-Ghazālī attacks the causality principle in order to demonstrate the possibility of extraordinary events, namely miracles as proofs of prophethood. Accordingly, al-Ghazāli attempts to rationalize miracles saying the following:

The contention over the first [theory] is necessary, inasmuch as [on its refutation] rests the affirmation of miracles that disrupt [the] habitual

5 Abū Ḥāmid Muḥammad ibn Muhammad al-Ghazālī, The Incoherence of the Philosophers (Tahāfut al-falāsifa; henceforth Tahāfut) (A parallel English-Arabic text translated, introduced and annotated by Michael E. Marmura; $2^{\text {nd }}$ ed., Provo, Utah: Brigham Young University Press, 2000), 163.

6 Ibn Rushd, Tahāfut al-Tahāfut (ed. Sulaymān Dunyā; Cairo: Dār al-Macārif, n.d.), II, 768 .

7 Ibn Rushd, Tahāfut al-Tahāfut, II, 767-768; cf. al-Ghazālī, Tahāfut, 161-163. 
[course of nature], such as the changing of the staff into a serpent, revival of the dead, the splitting of the moon. Whoever renders the habitual courses [of nature] a necessary constant makes all these [miracles] impossible. [The philosophers] have thus interpreted what is said in the Qur'ann about the revivification of the dead metaphorically, saying that what is meant by it is the cessation of the death of ignorance through the life of knowledge. ${ }^{8}$

Ibn Rushd objects to this attitude, which completely corresponds to his abovementioned classification. He says:

Of religious principles it must be said that they are divine things which surpass human understanding, but must be acknowledged although their causes are unknown. ${ }^{9}$

This analysis constitutes the basis of Ibn Rushd's theory related to philosophy of religion.

Therefore, we clearly see that the apologetic view of al-Ghazāli is associated with his conception of nature, and this is also the case for Ibn Rushd. When al-Ghazāli includes miracles within the rational domain by reducing the relationship between cause and effect to "possibility"; Ibn Rushd, contrarily, insists on the necessity of the cause-effect relationship and removes miracles from the rational domain. Evidently, this disagreement has significant consequences not only in terms of ontology and epistemology, but also with respect to philosophy of religion.

In order to better understand these consequences, we should look more closely at the discussion. Al-Ghazāli develops his position on causality using three arguments. His first assertion is that there is not a necessary relationship between cause and effect. For demonstration, he begins by denying the existence of the genuine necessary natures of objects. We may address the burning of cotton, for instance, when in contact with fire.

The first position is for the opponent to claim that the agent of the burning is the fire alone, it being an agent by nature [and] not by

8 Al-Ghazālī, Tahāfut, 163; cf. Ibn Rushd, Tahāfut al-Tahāfut, II, 770.

9 Ibn Rushd, Averroes' Tahafut al-Tahafut (The Incoherence of the Incoherence) (henceforth Averroes' Tahafut) (trans.with introduction and notes Simon van den Bergh; Cambridge: Cambridge University Press, 1987), 322; for Arabic text see Tahāfut al-Tahāfut, II, 791-792. 
choice, hence, incapable of refraining from [acting according to] what is in its nature after contacting a substratum receptive of it. And this is one of the things we deny. On the contrary, we say: The one who enacts the burning by creating blackness in the cotton, [causing] separation in its parts, and making it cinder or ashes is God, either through the mediation of His angels or without mediation. As for fire, which is inanimate, it has no action. For what proof is there that it is the agent? The have no proof other than observing the occurrence of the burning at the [juncture of] contact with the fire. Observation, however, [only] shows the occurrence [of burning] at [the time of the contact with the fire] but does not show the occurrence [of burning] by [the fire] and [the fact] that there is no other cause for it. For there is no disagreement [with the philosophers] that the infusion of spirit and of the apprehending and motive powers into the animal sperm is not engendered by the natures confined in heat, cold, moistness, and dryness; that the father does not produce his son by placing the sperm in the womb; and that he does not produce his life, sight, hearing, and the rest of the powers in him. It is known that these [come to] exist with [the placing of the sperm], but no one says that they [come to] exist by it. Rather, they exist from direction of the First, either directly or through the mediation of the angels entrusted with temporal things. This is what the philosophers who uphold the existence of the creator uphold in a conclusive manner, [our] discourse being [at this point in agreement] with them. ${ }^{10}$

There are three key points in this reasoning:

1. The cause and effect relationship as observed in nature is not necessary.

Ibn Rushd completely refuses such an assertion:

To deny the existence of efficient causes which are observed in sensible things is sophistry, and he who defends this doctrine either denies with his tongue what is present in his mind or is carried away by a sophistical doubt which occurs to him concerning this question. ${ }^{11}$

What Ibn Rushd means by "denying with his tongue what is present in his mind" is better understood through Aristotle's criticism of the Sophists: "In case one believes that it is the same to fall and not to

\footnotetext{
10 Al-Ghazālī, Tahāfut, 167; cf. Ibn Rushd, Tahāfut al-Tahāfut, II, 778-779.

11 Ibn Rushd, Averroes' Tahafut, 318; cf. Tahāfut al-Tahāfut, II, 781.
} 
fall into a well, he would not avoid the well or cliff on his way due to fear of falling!". ${ }^{12}$ Similarly, those who assert the contingency of the relationship between cause and effect always refrain from touching the fire; therefore they, similar to the Sophists, claim with their tongues the opposite of what they have in their hearts.

We already examined the clear conviction and proofs of Ibn Rushd regarding the necessity of the cause-effect relationship. In this regard, it is quite normal that he describes the assertion al-Ghazāli supported, which means the denial of the order in nature and knowledge of existence, as sophistry; this is because the denial of the necessity of the cause-effect relationship will also mean ignoring the hierarchy of being, in other words, the capacity to know the truth and, thus, being:

Now intelligence is nothing but the perception of things with their causes, and in this it distinguishes itself from all the other faculties of apprehension, and he who denies causes must deny the intellect. Logic implies the existence of causes and effects, and knowledge of these effects can only be rendered perfect through knowledge of their causes. Denial of cause implies the denial of knowledge, and denial of knowledge implies that nothing in this world can be really known, and that what is supposed to be known is nothing but opinion, that neither proof nor definition exist. ${ }^{13}$

Averroes adds a strong dialectical comment to these remarks:

Those who admit that there exists, besides necessary knowledge, knowledge which is not necessary, forms a judgment on slight evidence and imagines it to be necessary, whereas it is not necessary. ${ }^{14}$

In fact, criticism of al-Ghazāli in this mode, namely, of the lack of any proof other than perceiving of cotton's being in contact with fire and following this the burning of cotton, includes a significant point that should not be overlooked. Yet, substance is not perceived by the senses either; it is comprehended through the intellect. The cause of this comprehension is its phenomenal entirety within sensible qualities. Otherwise, we could talk about neither knowledge nor intellect. This conclusion is also evident in Ibn Rushd's statement that "intelli-

\footnotetext{
12 Ibn Rushd, Tafsī $r$ I, 398.

13 Ibn Rushd, Averroes' Tahafut, 319; cf. Tahāfut al-Tahāfut, II, 785.

14 Ibn Rushd, Averroes' Tahafut, 319-320; cf. Tahāfut al-Tahāfut, II, 785-786.
} 
gence is nothing but the perception of things with their causes, and in this it distinguishes itself from all the other faculties of apprehension, and he who denies causes must deny the intellect."

Thus the objection asserted by al-Ghazālī is invalidated because, just as the qualities within the phenomenal entirety belonging to an object impose the insensible essence of the object on intellect, another phenomenal entirety, namely, the fact that the cotton burns whenever it is brought into contact with fire, imposes on intellect that one is the cause of the other. To deny the necessity of the causeeffect relationship only because it cannot be perceived requires also the denial of substance for the same reason. This will mean the same as affirming the disorder of existing things.

Sure enough, one can question here whether the fact that fire always burns cotton proves that it will burn it again hereafter, in short, whether a phenomenon necessarily occurs for the $1001^{\text {st }}$ time just in the same way it occurred repeatedly for a thousand times. We think that Ibn Rushd would answer it as follows: The $1001^{\text {st }}$ phenomenon is as necessary as a thing's being that thing, namely, as necessary as present Socrates' being the same Socrates tomorrow.

In addition, Ibn Rushd highlights a far more dangerous consequence of denying efficient causes and directs the abovementioned dialectical objection at his opponent: "He who denies this can no longer acknowledge that every act must have an agent". ${ }^{15}$ Therefore, it is impossible for someone who denies the cause-effect relationship to prove that there is an agent for each act; in this case, it will be equally impossible to think of God as a cause beyond the sensible cause. Therefore, kalām scholars abolish the belief for the sake of which they deny the principles of being.

\section{Things do not have any necessary nature at all.}

No doubt, this claim is also unacceptable for Ibn Rushd. Because, when al-Ghazālî's criticism of causality based on the denial of necessary nature, Ibn Rushd's defense of it is grounded in the approval of necessary nature. At this point, we can understand the categorical similarity between Ibn Rushd's criticisms of Ash'arīs and Aristotle's comments about Sophists.

15 Ibn Rushd, Averroes' Tahafut, 318; cf. Tahāfut al-Tahāfut, II, 781. 
Just as Sophists cannot conceive the essence behind the changing qualities, Ash'arīs denied the necessity of the cause-effect relationship, and consequently the necessary nature of things in order to prove the possibility of miracles through reason. As a result, kalām scholars, at least in the eyes of Ibn Rushd, have sunk into relativism just like the Sophists. Yet, to deny the cause-effect relationship will equally mean to deny the thing that is cause or the effect; that makes one thing what it is, namely, the essential cause. In consequence, no definite or constant thing will remain in universe:

And further, what do the theologians say about the essential causes, the understanding of which alone can make a thing understood? For it is self-evident that things have essences and attributes which determine the special functions of each thing and through which the essences and names of things are differentiated. If a thing had not its specific nature, it would not have a special name nor a definition, and all things would be one - indeed, not even one. ${ }^{16}$

According to Ibn Rushd, the mistake of the Ash'aris here arises from their lack of ability to go beyond the effort to justify their prejudgments, as opposed to trying to comprehend nature independent of any kind of prejudgment. They have, in order to glorify God, asserted God as the only agent in the universe and tried to prove this assertion by means of sophistic proofs:

As for men of our day, they have imposed one immediate agent for all acts of beings, and that is almighty God. Therefore, according to them, no one among all beings should have a peculiar act with which God has stamped. If beings have no peculiar acts, it means, then, that they do not have peculiar essences because acts differentiate only according to the differentiation of essences. Once essences are abolished, so are names and definitions. Consequently all beings become a single thing. This view is seriously strange to human nature. The motive to lead them to such a thought is their closing the doors of thinking. They invite to thinking, but deny its principles. They are dragged to all of these conclusions because they suppose that only such this manner will lead us to a right faith in $\operatorname{sharì}^{\mathrm{c}} a$. All these, however, are nothing but their ignorance of $\operatorname{sharī}^{c} a$ or their obstinacy outwardly, not inwardly. ${ }^{17}$

16 Ibn Rushd, Averroes' Tahafut, 318; cf. Tahāfut al-Tahāfut, II, 782-783.

17 Ibn Rushd, Tafsī $r$, II, 1135-1136. 
3. The formal substance, which provides the nature peculiar to each thing, is given by an agent separate from the matter, that is God or through the intermediation of angels, not by things of the same kind.

Two previous articles criticized the necessity of the cause-effect relationship between things in nature. On the other hand, the continuous change in generation should be explained, and this requires a causal relationship. At this point, al-Ghazālī explains generation by claiming that there is no agent other than God. Therefore, al-Ghazāli indicates that there is nothing necessary apart from God's will and His creation.

We would like to illuminate a significant point before discussing that issue. It seems that al-Ghazālī's only references in philosophical sciences are to al-Fārābī and Ibn Sīnā. Al-Ghazālī probably never analyzed the works of Aristotle. This can be demonstrated by two proofs:

1. The philosophers al-Ghazālī refers to as "who believe in God" are Socrates, Plato, and his disciple Aristotle. According to al-Ghazālī, Aristotle criticized Socrates, Plato, and all other philosophers of metaphysics, and became distant from them. Aristotle developed the science of logic into a method, completed the philosophical sciences more than ever, and made them clear. ${ }^{18}$ However, it is Plato who affirms that the efficient cause cannot be physical, whereas Aristotle argues that the non-physical cannot influence the physical. Moreover, the longest chapters of his Metaphysics consist of a criticism of Plato's view in question. As we will soon examine in detail, it is al-Fārābī and Ibn Sinnā who identify Aristotle as the source of this view. In this case, because al-Ghazālī says, "This is among the points definitely accepted by philosophers who believe in God," it can be inferred that he has never read Aristotle.

2. Al-Ghazālī explicitly states that al-Fārābī and Ibn Sīnā are the most perfect commentators on Aristotle, and he considers the works of others in this matter unworthy of reading:

18 Al-Ghazālī, Deliverance from Error and Attachment to The Lord of Might and Majesty [al-Munqidh min al-dalāl], in W. Montgomery Watt (trans.), The Faith and Practice of al-Ghazālī (London: George Allen and Unwin, 1953), 32; for the Arabic text see al-Ghazālī, al-Munqidh min al-ḍalāl (eds. Jamīl Ṣalībā and Kāmil 'Ayyād; $7^{\text {th }}$ ed., Beirut: Dār al-Andalus, 1967), 77. 
None of the Islamic philosophers has accomplished anything comparable to the achievements of the two men named. The translations of others are marked by disorder and confusion, which so perplex the understanding of the student that he fails to comprehend; and if a thing is not comprehended how can it be either refuted or accepted?"19

These phrases reveal that al-Ghazālī's only sources concerning Aristotle are al-Fārābī and Ibn Sīnā.

After clarifying this problem, we can now address the concept of formal substance that constitutes, in our opinion, the key point of causality in the philosophy of Ibn Rushd.

After denying the necessity of a causal relationship in nature, and even claiming the nonexistence of such a relationship, al-Ghazāli ignored the idea that each existent possesses a necessary and constant nature. The insistence of kalām in this issue seems to be closely related to their conceptions of God and fate (qadar). Hereafter, alGhazālī attempts to explain generation by means of a concept, which, as we will see, he adopts from al-Fārābī and especially Ibn Sīnā.

According to al-Ghazālī, generation has occurred by immediate act of God or by means of His angels. In justifying this, he tries to prove that the formal substance, which is the cause of coming into existence, is given to matter by an agent separate from it. According to al-Ghazālī, philosophers who believe in God have accepted that the forms emanate to the matter from the angels, which they call the principles of being, and that species and genera come into existence in this way: "For this reason, wheat has never sprouted from barley, and apples never from the seed of pears". ${ }^{20}$

However, later on al-Ghazālì begins to adduce proofs in order to demonstrate that the agent of this emanation is separate from the matter and in order to ignore that the beings in nature cause each other. For example, according to al-Ghazālī, worms reproduce from soil, not from each other, similarly, mice, snakes, and scorpions can reproduce from the soil, as well as from each other. Therefore, the formal substance, which ensures the formation of species and genera

\footnotetext{
19 Al-Ghazālī, Deliverance, 32; also see ibid., al-Munqidh, 78.

20 Al-Ghazālī, Tahāfut, 173; cf. Ibn Rushd, Tahāfut al-Tahāfut, II, 801.
} 
and is the cause of any coming into existence, is separated from the matter; as a result, the formal substance is given to matter by an agent that is separate from the matter. Al-Ghazālī thinks that the philosophers agree with him. He says: "Our statement in [answering your question] is the same as your statement in [answering ours]. It is, however, more fitting for both you and us to relate this to God, either directly or through the mediation of the angels." ${ }^{21}$

As we have seen, the main problem al-Ghazāli emphasizes is the denial of the cause-effect relationship between physical objects; in this way, it will be revealed that the cause of generation is an immaterial being; thus, the possibility of miracles will be justified. Besides, al-Ghazālī does not refrain from bringing evidence from practices such as magic, talismanic art, and astrology in order to strengthen his analysis. For example, talisman practitioners can dispel scorpions, snakes, and bedbugs from a certain place through charms they apply in accordance with the positions of celestial bodies. Therefore, "whoever studies [inductively] the wonders of the sciences", such as talismanic practice, soothsaying, sorcery and fortunetelling, "will not deem remote from the power of God, in any manner whatsoever, what has been related of the miracles of the prophets." ${ }^{22}$

Al-Ghazāli thinks that he attains his goal through this argumentation. Nevertheless, Ibn Rushd thinks very differently in accordance with his philosophy and offers some important criticisms.

1. According to Ibn Rushd, the assertion that the formal substance is separate from the matter and given to the matter by an agent separate from matter, such as God or angels, is a Platonist view; as for Aristotle, he thinks the opposite and claims that formal substance is immanent to the material being. In fact, this point is one of the sharpest distinctions between Plato and Aristotle, and it is discussed in several chapters of Aristotle's Metaphysics.

However, it seems that Muslim philosophers are seriously on the wrong track here, especially because of apocryphal Theologia. In this context, Ibn Rushd's achievement in revealing the true Aristotle is remarkable:

21 Al-Ghazālī, Tahāfut, 172; cf. Ibn Rushd, Tahāfut al-Tahāfut, II, 800.

22 Al-Ghazālī, Tahāfut, 174; cf. Ibn Rushd, Tahāfut al-Tahāfut, II, 802. 
The community [Mashshā's̄is] could not comprehend Aristotle's justification of this problem and could not have a grasp of its true meaning. It is not only Ibn Sīnā but also Abū Naṣr [al-Fārābī] who surprises us! The latter's work Kitāb fi l-falsafatayn [Book on the Two Philosophies; i.e. philosophies of Platon and Aristotle] reveals that he had a suspicion in this regard. The community [Mashshā'īs] inclined towards the Platonist view, because it is very close to the conviction of theologians of our religion concerning this issue that "the agent of everything is one and beings cannot cause each other." That is, they thought that if beings cause each other, it would require the infinite regression in the series of efficient causes, consequently they asserted that there must be an agent which is not a body $\left(\right.$ jism) ${ }^{23}$

2. According to Ibn Rushd, the explanation of formal substance is the most important issue in philosophy. Even more, he states that because of this Tahaffut is not the appropriate place to explain this problem and that those who want to learn its true solution should follow the right way. ${ }^{24}$ By this, he no doubt means an analysis of the works of Aristotle.

This is why we will bypass the discussion in Tahäfut and examine Ibn Rushd's philosophical explanations to that end.

Ibn Rushd strictly follows Aristotle on this theme; so he purified the philosophy of Aristotle from syncretic confusions traced to the Hellenistic period, and that this achievement raised Ibn Rushd to the position of an original thinker.

According to Ibn Rushd, at this point, the essence of what Aristotle said is that, even if there are separate forms here, they are not sufficient to bring into existence. Generation occurs only through things that are the same in terms of form but distinct with respect to number". ${ }^{25}$ Here, we discover that Ibn Rushd turns towards explaining generation in nature through formal substance that is never separate from the matter and exists immanently within individuals.

Naturally, according to Ibn Rushd, that which is separate from the matter cannot act on the material. In this regard,

\footnotetext{
23 Ibn Rushd, Tafsìr , II, 886.

24 Ibn Rushd, Tahāfut al-Tahāfut, II, 788.

25 Ibn Rushd, Tafsir , II, 881.
} 
necessarily, just as how each material thing should generate from the material, the immaterial thing should definitely generate from the immaterial. ${ }^{26}$

The exact opposite of this view was Platonism, which explained generation with forms separate from matter, namely, ideas. According to Ibn Rushd, al-Fārābī and Ibn Sīnā used Platonist analysis, distorting Aristotle, in order to reconcile these two opposite views, as well as they were unable to comprehend Aristotle's arguments.

3. Proofs of the separation between formal substance and matter by al-Ghazālī, who introduces them as his own invention, are nothing but a repetition of those asserted by Plato:

This discourse of Aristotle comprises suspicions that are hard [to resolve], as well as strong difficulties. That is, even if we assume that a thing which is potential (bi-l-quwwa) becomes actual (bi-l-fict) only via something in the same species and genus, because we see that many animals and plants breed without fertilization from something of the same kind in form, one can think that there should be certain [separate] substances and forms that give the forms of animals and plants to the animals and plants being generated. This is the most important argument in favor of Plato and against Aristotle. ${ }^{27}$

Yet, all comings into existence in nature consist of natural things, and they generate from matter. The same is true for products of crafts. However, in the first case the agent is nature itself, whereas in the second case the craftsman. Therefore, "similarly, what forms the 'formed thing (al-mutakawwin)' possessing a form and nature is a nature and form, as in 'man' in natural things and 'house' in crafts. ${ }^{28}$ Nevertheless, generation does not merely consist of natural things and products of arts; there are also what are generated by chance, because the matter sometimes has a spontaneous movement in itself.

The condition of objects formed by nature is similar to that of objects which are products of crafts:

Things brought into existence by nature are similar to objects which are artistic productions; the sperm (or seed $[z a r]$ ) acts on what is formed through a potentiality similar to the art in itself. In other

\footnotetext{
26 Ibn Rushd, Tafsīr, II, 886.

27 Ibn Rushd, Tafsìr, II, 881.

28 Ibn Rushd, Tafsì $r$, II, 840.
} 
words, this is the essence of the formed. Just as how the form of the artefact is preexisted in the mind of the artisan, so the form of the formed is potentially present in sperm. ${ }^{29}$

Hereby, the entity that is created from the sperm itself and the thing that is formed by the sperm share the same name. That is, man emerges from man. "But," states Averroes,

... we said that they are like a begotten species and its father because there is not an offspring absolutely and in all aspects identical to the father; just as when a male human can breed from a male human, so a female human can also come into existence through a male human. ${ }^{30}$

The reason for this is a slight deficiency with respect to the form transmitted by the sperm. Furthermore, there are more extreme deficiencies of form in nature; for example, a mule is the offspring of a horse and a donkey, but it cannot generate from each other due to the deficiency of the potential form in its sperm. ${ }^{31}$

Consequently, we can touch upon al-Ghazālī's most important proof of the separation of formal substance and matter, which analyzes the parthenogenetic animals such as worms, mice, and snakes. As indicated above, according to Ibn Rushd apart from things generated by nature or by art, there are things generated by chance due to the spontaneous movement in their matter. That is the reason of selfgeneration of certain creatures in nature.

Anything that comes into being from not its synonym but itself is generated in a manner like the generation of things whose matter (or sperm) has a potentiality from which a synonym is generated ... The creatures that are not generated from their own genera and that are not born [that come into existence themselves] do not bear in their matter the potentiality to produce their synonyms. Likewise, this kind of living thing comes into existence in a manner different from the occurrence of accidents, as well as from generation through the aggregation of accidents or generation through sperm or seed. ${ }^{32}$

It is clear that Averroes refuses to explain the generations in nature by means of certain supernatural agents. But what are we to say

\footnotetext{
29 Ibn Rushd, Tafsìr, II, 879.

30 Ibn Rushd, Tafsìr, II, 880.

31 Ibn Rushd, Tafsìr, II, 880.

32 Ibn Rushd, Tafsìr, II, 880.
} 
about the fact that Platonists defend themselves by asserting abiogenesis against the Aristotelian criticisms of the theory of ideas? Given that Aristotle also admits abiogenesis, does not the generation of a living thing from inorganic matter - and also without sperm - indicate the influence of a substance separate from the matter?

Ibn Rushd, as a strict follower of Aristotle, refuses to associate abiogeneration with the influence of active intellect separate from the matter and thus definitely separates the realms of physical and nonphysical beings - at least in terms of efficient causality. This attitude clearly diverges from the interpretation of al-Fārābī and Ibn Sīnā, who consider the non-physical active intellect to be the efficient cause of not only knowledge but also of generation. Therefore, it is not surprising that Ibn Sinna classifies practices that seek ways of acting on material objects by means of immaterial causes, including talismanic art, magic, fortunetelling, etc., among the natural sciences. It is historically wrong for al-Ghazālī, who addresses the Avicennian thought, to incline toward a total refusal as if Aristotle were of the same opinion with Ibn Sinnā. For Ibn Rushd, the self-generation of certain creatures is a phenomenon that has nothing to do with practices like talismanic art or magic; it is about deficiency and disorder with respect to formal substance. Besides, certain anomalies in nature do not show that the efficient cause of generation is a power separate from the matter. On the contrary, scientific proof points out that the agent of what is physical is again a physical thing.

This opinion may certainly appear to be a type of materialism at first glance. Nonetheless, Aristotle and Ibn Rushd definitely accept the existence of a realm of non-physical things. Moreover, this realm is more perfect than the realm of physical things. All the same, another point to be emphasized is that the causal relationship between the physical and the non-physical is established not by efficient cause, but with respect to final cause. Therefore, even though the non-material does not act on the material, it possesses a superior directive position in virtue of its being a final cause. Here lies the strength of the solution brought by the Muslim philosopher Ibn Rushd to the problem. 


\section{REFERENCES}

Al-Ghazālī, Abū Ḥāmid Muḥammad ibn Muḥammad, al-Munqidh min aldalāl (eds. Jamīl Șalībā and Kāmil 'Ayyād; $7^{\text {th }}$ ed., Beirut: Dār alAndalus, 1967).

Deliverance from Error and Attachment to The Lord of Might and Majesty [al-Munqidh min al-dalāl, in W. Montgomery Watt (trans.), The Faith and Practice of al-Ghazāli (London: George Allen and Unwin, 1953), 19-85.

The Incoherence of the Philosophers (Tahäfut al-falāsifa) (A parallel English-Arabic text translated, introduced and annotated by Michael E. Marmura; $2^{\text {nd }}$ ed., Provo, Utah: Brigham Young University Press, 2000).

Ibn Rushd, Abū 1-Walīd Ibn Rushd al-Ḥafīd Muhammad ibn Aḥmad alQurțubī, Tafsìr Mā ba'd al-țabī'a, 3 vols., (ed. Maurice Bouyges; Beirut: Dār al-Mashriq, 1991).

Tahāfut al-Tahāfut, 2 vols., (ed. Sulaymān Dunyā; Cairo: Dār alMacārif, n.d.) Averroes' Tahafut al-Tahafut (The Incoherence of the Incoherence), 2 parts in 1 volume, (trans.with introduction and notes Simon van den Bergh; Cambridge: Cambridge University Press, 1987).

Ibn Sīnā, Abū 'Alī Ḥusayn ibn 'Abd Allāh ibn 'Alī, Risāla fì aqsām al-'ulūm al-aqliyya, in Rasā'il fì l-bikma wa-l-țabī'iyyāt (Istanbul: Maṭba'at alJawā’ib, 1298 H.) 